\title{
KEEFEKTIFAN PENDEKATAN KONSTRUKTIVISME TERHADAP KEMAMPUAN PENALARAN MATEMATIS MAHASISWA PADA MATA KULIAH ANALISIS REAL
}

\author{
Fitriani $^{1}$, Yulia Anita Siregar ${ }^{2}$ \\ ${ }^{1,2}$ Dosen Program Studi Pendidikan Matematika Universitas Muhammadiyah Tapanuli Selatan \\ ${ }^{1}$ fi3ani.hrp@gmail.com, ${ }^{2}$ yulia_regar@yahoo.co.id
}

\begin{abstract}
This research was conducted at University of Muhammadiyah South Tapanuli in semester VI student of mathematics education program that follow Real Analytical course. This study aims to determine students' mathematical reasoning ability after using constructivism approach and also want to know the effectiveness of constructivism approach to mathematical reasoning ability, as well as expected to give benefit to lecturer of Real Analysis course lecturer. The method used to achieve the goal is by experimental method with pre-experimental design research design. This research produces: A very effective constructivism approach is used to teach real analysis courses. There is an increase in students' mathematical reasoning abilities after using constructivism approach.
\end{abstract}

Keywords: Constructivism, Mathematical Reasoning, Real Analysis.

\begin{abstract}
Abstrak. Penelitian ini dilakukan di Universitas Muhammadiyah Tapanuli Selatan pada mahasiswa semester VI program studi pendidikan matematika yang mengikuti mata kuliah Analisi Real. Penelitian ini bertujuan untuk mengetahui kemampuan penalaran matematis mahasiswa setelah menggunakan pendekatan konstruktivisme dan juga ingin mengetahui efektifitas pendekatan konstruktivisme terhadap kemampuan penalaran matematis, sekaligus diharapkan dapat memberikan manfaat kepada dosen pengampu mata kuliah Analisis Real. Metode yang digunakan untuk mencapai tujuan tersebut ialah dengan metode eksperimen dengan desain penelitian pre-experimental design. Penelitian ini menghasilkan: Pendekatan konstruktivisme sangat efektif digunakan untuk mengajarkan mata kuliah analisis real, Terjadi peningkatan kemampuan penalaran matematis mahasiswa setelah menggunakan pendekatan konstruktivisme.
\end{abstract}

Kata Kunci: Konstruktivisme, Penalaran Matematis, Analisis Real.

\section{PENDAHULUAN}

Analisis real adalah salah satu cabang dari analisis matematika yang berhubungan dengan himpunan bilangan real dan fungsi real variabel dan tujuan diberikannya mata kuliah analisis real merupakan sarana untuk melatih mahasiswaberpikir logis atau melakukan penalaran secara benar. Hal ini sejalan sejalan dengan cirimata kuliah tersebut yaitu sarat dengan definisi dan teorema serta merupakan matakuliah dengan struktur deduktif aksiomatik yang ketat (Septiati, 2012). Maka salah satu kemampuan matematika yang harus dimiliki pada mata kuliah analisis real ialah bernalar atau penalaran pada pola, sifat, dalil-dalil, teorema-teorema, collorali, melakukan manipulasi, menyusun bukti, menjelaskan gagasan dan menjelaskan pernyataan matematika.Hal ini didukung oleh Ball, Lewis \& Thamel (dalam Riyanto, 2011) bahwa "mathematical reasoning is thefoundation for the construction of mathematicalknowledge". Hal ini berarti penalaranmatematika adalah fondasi untuk mendapatkanatau menkonstruk pengetahuan matematika.

Berdasarkan hasil observasi terhadap nilai UAS mahasiswa pada semester sebelumnya menunjukkan bahwa kemampuan penalaran matematika mahasiswa baik secara keseluruhan maupun dikelompokkan menurut tahap kognitifnya, skor 
kemampuan penalaran matematis mahasiswa masih rendah.Berdasarkan hal tersebut maka dengan pendekatan konstruktivisme diharapkan mampu meningkatkan keaktifan siswa, siswa mampu menyampaikan ide-ide/ gagasan yang berhubungan dengan materi yang sedang dipelajari, sehingga mampu meningkatkan kemampuan matematis mahasiswa. Jadi menurut Ansari (2009) teori ataupun pendekatan konstruktivisme, belajar adalah keterlibatan anak secara aktif membangun pengetahuannya melalui berbagai jalur, seperti membaca, berpikir, mendengar, berdiskusi, mengamati dan melakukan eksperimen terhadap lingkungan serta melaporkannya. Sehingga secara tidak langsung pendekatan konstruktivisme dapat meningkatkan kemampuan penalaran mahasiswa.

\section{METODE}

Jenis penelitian ini adalah penelitian kuantitatif. Menurut Sugiyono (2009) penelitian kuantitatif adalah penelitian yang digunakan untuk meneliti pada populasi atau sampel tertentu, pengumpulan data menggunakan instrumen penelitian, analisis data bersifat kuantitatif/statistik, dengan tujuan untuk menguji hipotesis yang telah ditetapkan.

Metode penelitian yang digunakan dalam penelitian ini adalah metode eksperimen, dengan desain penelitian pre-experimental design. Teknik pengumpulan data yang digunakan dalam penelitian ini adalah menggunakan tes berdasarkan indikator kemampuan penalaran matematis dan lembar observasi terhadap kemampuan dosen mengelola pembelajaran yang mengajarakan mata kuliah analisis real dengan pendekatan konstruktivisme.Analisis data kemampuan penalaran matematis terhadap pendekatan konstruktivisme di analisi dengan menggunakan uji t, sedangkan kemampuan dosen mengelola pembelajaran menggunakan kriteria kemampuan dosen mengelola pembelajaran.

\section{HASIL DAN PEMBAHASAN \\ Kemampuan Penalaran}

Tes yang diberikan kepada mahasiswa berupa pre tes dan pos tes. Pre tes diberikan untuk mengetahui kemampuan awal mahasiswa sebelum menggunakan pendekatan konstruktivisme, sedangkan pos tes diberikan untuk mengetahui kemampuan penalaran mahasiswa sesudah menggunakan pendekatan konstruktivisme yang diukur berdasarkan indikator penalaran itu sendiri. Berikut adalah tabel 1 hasil perhitungan yang diperoleh berdasarkan data pre tes dan pos tes mahasiswa.

Tabel 1. Hasil Perhitungan dari Data Pre Tes dan Pos Tes

\begin{tabular}{lrr}
\hline \multicolumn{1}{c}{ Keterangan } & Pre tes & Pos tes \\
\hline Rata-rata & 63,86956522 & 78,26086957 \\
\hline Standar Deviasi & 7,344164955 & 6,347636577 \\
\hline Varians & 53,93675889 & 40,29249012 \\
\hline $\mathrm{r}_{\mathrm{xy}}$ & 0,764220116 & \\
\hline $\mathrm{t}_{\text {hitung }}$ & 14,39872956 \\
\hline $\mathrm{t}_{\text {tabel }}$ & 2,021 \\
\hline Kesimpulan & $\mathrm{t}_{\text {hitung }}>\mathrm{t}_{\text {tabel }}$ & \\
\hline
\end{tabular}

Berdasarkan perhitungan yang diperoleh dari pre tes dan pos tes dapat dilihat terjadi peningkatan nilai mahasiswa sebesar 14,4 berdasarkan nilai rata-rata. Selain itu dilihat dari hubungan atau nilai r juga berada pada kategori kuat ini berarti bahwa ada 
hubungan antara pendekatan konstruktivisme terhadap kemampuan penalaran matematis. Maka untuk mengetahui peningkatan kemampuan penalaran matematis siswa, selanjutnya data tersebut dianalisi menggunakan uji t. Berdasarkan perhitungan yang dilakukan diperoleh nilai t hitung sebesar 14, 398 sedangkan nilai t tabel pada $\mathrm{dk}=44$ dan $\alpha=5 \%$ ialah 2,021 sehingga dapat disimpulkan bahwa $\mathrm{t}_{\text {hitung }}>\mathrm{t}_{\text {tabel, }}$, ini berarti terdapat perbedaan yang signifikan kemampuan penalaran matematis mahasiswa pada mata kuliah analisis real antara sebelum dan sesudah menggunakan pendekatan konstrukstivisme. Kesimpulannya adalah pemberian pendekatan konstruktivisme berpengaruh terhadap peningkatan kemampuan penalaran matematis mahasiswa pada mata kuliah analisis real.Serta Terjadi Peningkatan Kemampuan Penalaran Matematis Mahasiswa Setelah Mengikuti Perkuliahan Analisis Real Menggunakan Pendekatan Konstruktivisme.

\section{Keefektifan Pendekatan Konstruktivisme}

Untuk mengukur keefektifan pendekatan konstruktivisme yaitu menggunakan lembar observasi. Dalam penelitian ini yang di observasi ialah hanya satu arah saja yaitu hanya melihat kemampuan dosen mengelola pembelajaran yang mengajarakan mata kuliah analisis real dengan pendekatan konstruktivisme. Proses pembelajaran yang di ukurialah selama 6 kali pertemuan. Pendeskripsian skor rata-rata mengadopsi pendeskripsian skor rata-rata yang digunakan oleh Mukhlis (Siregar, 2011) seperti tabel 2 berikut.

Tabel 2. Kriteria Kemampuan Dosen Mengelola Pembelajaran

\begin{tabular}{ccc}
\hline No & $\begin{array}{c}\text { Nilai Rata-Rata Tingkat } \\
\text { Kemampuan Guru }\end{array}$ & $\begin{array}{c}\text { Kriteria Kemampuan } \\
\text { Guru }\end{array}$ \\
\hline 1 & $1,00-1,49$ & Tidak Baik \\
\hline 2 & $1,50-2,49$ & Kurang Baik \\
\hline 3 & $2,50-3,49$ & Cukup Baik \\
\hline 4 & $3,50-4,49$ & Baik \\
\hline 5 & $4,50-5,00$ & Sangat Baik \\
\hline
\end{tabular}

Kemampuan guru dalam mengelola pembelajaran dikatakan efektif/bak jika skor dari setiap aspek yang dinilai berada pada kategori: "baik" atau "sangat baik".Berikut adalah hasil observasi yang di peroleh observer selama kegiatan proses pembelajaran.

Tabel 3. Hasil Observasi Kemampuan Dosen Mengelola Pembelajaran Menggunakan Pendekatan Konstruktivisme

\begin{tabular}{llcccccc}
\hline & & \multicolumn{7}{c}{ Pertemuan } \\
\cline { 3 - 8 } No & \multicolumn{1}{c}{ Kegiatan/Aspek yang diamati } & 1 & 2 & 3 & 4 & 5 & 6 \\
\cline { 2 - 8 } & $\begin{array}{c}\text { Rata- } \\
\text { rata }\end{array}$ & $\begin{array}{c}\text { Rata- } \\
\text { rata }\end{array}$ & $\begin{array}{c}\text { Rata- } \\
\text { rata }\end{array}$ & $\begin{array}{c}\text { Rata- } \\
\text { rata }\end{array}$ & $\begin{array}{c}\text { Rata- } \\
\text { rata }\end{array}$ & $\begin{array}{c}\text { Rata- } \\
\text { rata }\end{array}$ \\
\hline 1 & 4 & 4,5 & 4 & 4 & 4 & 4 \\
\hline $\begin{array}{l}\text { Pendahuluan terdiri dari } \\
\begin{array}{l}\text { (1) Menyampaikan tujuan } \\
\text { pembelajaran }\end{array}\end{array}$ & 4 & 4,5 & 4 & 4 & 4 & 3,5 \\
\hline $\begin{array}{l}\text { (2) Memotivasi mahasiswa. } \\
\text { Kegiatan inti terdiri dari }\end{array}$ & 4 & 4 & 5 & 5 & 4,5 & 4 \\
\hline $\begin{array}{l}\text { (1) Menyajikan informasi } \\
\begin{array}{l}\text { (2) Mengorganisasikan mahasiswa } \\
\text { untuk belajar }\end{array}\end{array}$ & 4 & 5 & 4,5 & 5 & 4 & 5 \\
\hline
\end{tabular}




\begin{tabular}{|c|c|c|c|c|c|c|c|}
\hline & $\begin{array}{l}\text { (3) Membimbing mahasiswa } \\
\text { menemukan jawaban }\end{array}$ & 3 & 5 & 5 & 5 & 5 & 4,5 \\
\hline & (4) Memberikan evaluasi & 3 & 4 & 4 & 4 & 3,5 & 4 \\
\hline & (5) Memberikan penghargaan. & 3 & 4 & 4 & 4 & 3,5 & 3,5 \\
\hline 3 & Penutup terdiri dari & & & & & & \\
\hline & $\begin{array}{l}\text { (1) Menegaskan kembali kesimpulan } \\
\text { materi, }\end{array}$ & 4 & 5 & 5 & 5 & 5 & 5 \\
\hline & $\begin{array}{l}\text { (2) Memberi beberapa soal sebagai } \\
\text { tugas mandiri. }\end{array}$ & 3,5 & 4 & 4 & 4 & 3,5 & 3 \\
\hline 4 & $\begin{array}{l}\text { Pengelolaan waktu } \\
\text { pembelajaran }\end{array}$ & 3 & 5 & 4 & 4 & 4 & 4 \\
\hline 5 & Suasana di kelas terdiri dari & & & & & & \\
\hline & $\begin{array}{l}\text { (1) Antusias mahasiswa mengikuti } \\
\text { pembelajaran }\end{array}$ & 3 & 4 & 4,5 & 4 & 5 & 5 \\
\hline & $\begin{array}{l}\text { (2) Antusias guru mengelola } \\
\text { pembelajaran. }\end{array}$ & 3,5 & 5 & 4 & 4 & 5 & 5 \\
\hline & Jumlah setiap pertemuan & 42 & 54 & 52 & 52 & 51 & 50,5 \\
\hline & Rata-rata setiap pertemuan & 3,5 & 4,5 & 4,33 & 4,33 & 4,25 & 4,20 \\
\hline & Jumlah total & \multirow{2}{*}{\multicolumn{6}{|c|}{$\begin{array}{c}25,125 \\
4.18\end{array}$}} \\
\hline & Rata-rata total & & & & & & \\
\hline
\end{tabular}

Berdasarkan hasil yang diperoleh terlihat bahwa masing-masing rata-rata pada setiap pertemuannya adalah pertemuan $1=3,5$, pertemuan $2=4,5$, pertemuan $3=$ 4,33 , pertemuan $4=4,33$, pertemuan $5=4,25$, dan pertemuan $6=4,20$. Jika ditinjau dari setiap aspek maka kemampuan dosen masih ada yang berada dalam kategori "cukup baik" (nilai 3).Namun berdasarkan rata-rata dari setiap pertemuannya maka kemampuan dosen dalam mengelola pembelajaran dengan pendekatan konstruktivisme adalah berada pada kategori "baik" dan "sangat baik". Sehingga berdasarkan hasil yang diperoleh pada setiap pertemuannya maka penggunaan pendekatan konstruktivisme dalam mengajarkan mata kuliah analisis real adalah "efektif" dan "sangat efektif". Tetapi secara rata-rata keseluruhan nilai yang diperoleh ialah 4,18 ini berada pada kategori "baik" ataupun "efektif".

\section{KESIMPULAN}

Dari penelitian yang telah dilakukan dan berdasarkan analisis yang dilakukan diperoleh kesimpulan bahwa: Pendekatan konstruktivisme sangat efektif digunakan untuk mengajarkan mata kuliah analisis real.Terjadi Peningkatan Kemampuan Penalaran Matematis Mahasiswa Setelah Mengikuti Perkuliahan Analisis Real Menggunakan Pendekatan Konstruktivisme.

\section{UCAPAN TERIMAKASIH}

Pada kesempatan ini peneliti mengucapkan terima kasih kepada: Universitas Muhammadiyah Tapanuli Selatan yang telah memeberikan bantuan dana dan sebagai tempat untuk melakukan kegiatan penelitian ini, LPPM Universitas Muhammadiyah Tapanuli Selatan sebagai Penyelenggara penelitian dan pengabdian masyarakat.

\section{DAFTAR PUSTAKA}

Ansari, Bansul I. 2009.Komunikasi Matematik Konsep dan Aplikasi. Banda Aceh: PeNA. 
Riyanto, Bambang. 2011. Meningkatkan Kemampuan Penalaran dan Prestasi Matematika dengan Pendekatan Konstruktivisme pada Siswa Sekolah Menengah Atas. Jurnal Pendidikan Matematika, Volume 5. No. 2 Juli 2011.

Septiati, Ety. 2012. Keefektifan Pendekatan Konstruktivisme Terhadap Kemampuan Koneksi Matematis Mahasiswa pada Mata Kuliah Analisis Real I. Prosiding ISBN: 978-979-16353-8-7. Makalah dipresentasikan dalam Seminar Nasional Matematika dan Pendidikan Matematika dengan tema "Kontribusi Pendidikan Matematika dan Matematika dalam Membangun Karakter Guru dan Siswa" pada tanggal 10November 2012 di Jurusan Pendidikan Matematika FMIPA UNY.

Siregar, Sakinah Ubudiah. 2011. Pengembangan Perangkat Pembelajaran Berbasis Masalah dalam Peningkatan Kemampuan Pemecahan Masalah Siswa Kelas V MIN pada Pokok Bahasan Pecahan.Medan: Program Pascasarjana Unimed Medan.

Sugiyono. 2009. Metode Penelitian kuantitatif, kualitatif dan $R \& D$. Bandung: Alfabeta. 